性がある。もっとnーヘキサン使用についてる調査する 必要があるのではないか。

53：（質問，河合）トルェン以外の溶剤については調 查したのか.（答）トルェン以外に MEK，nーヘキサン 等が入っていたが，トルエンが主成分であったので，ト ルエンKついて解析した．（質問，河合）図4はBSC 法 によるものか HPLC 法によるものか. (答) HPLC 法に よって結果を図示した。（質問, 山田）トルエンの個人 暴露量が $100 \mathrm{ppm}$ 以下であったが，尿中馬尿酸排渫量 のスクリーニングレベル $1.79 \mathrm{~g} / l$ (池田) より高值を示 すものが多かったといらが，皮膚からの吸収は検討した か.（答）経皮吸收は今回はよく調べていない（追加， 池田）私の提案したスクリーニングレベルはガスバッチ も高速液クロもない時期のもので数值自体は再検討が必 要と考学ている。またスクリーニングレベルは集団とし ての暴露量評価のためのもの之個人暴露量の評価のため のものと区別する必要があると考学る.

\section{4. 自動車塗装工の有機溶剤暴露}

畧 博, 江崎廣次, 仲吉則雄, 渡辺大介 馬郡良英，百瀬義人，松永純子，前田真澄 加茂弘子（福岡大医）

自動車整備工場比打る塗装作業者の有機溶郕暴露の 実態を知るために，有機溶剂暴露時間々有機溶剂暴露濃 度を測定し，同時に尿中馬尿酸の経時的測定を合わせて 実施した。

その結果，叙装中の作業環境涱度はいずれも許容濃度 以下であった，また，塗装中の個人暴露濃度は，横引き 型ブース内 >ブース外>プッシニプル型ブース内の順 で，横引き型ブース内掠よびブース外塗装中のトルェン 濃度は許容濃度を超えていた。塗装時間は全員 1 時間以 内で，比較的短かった．各溶剤の時間荷重平均濑度を許 容濃度で除して加算した值 $\Sigma C_{i} / T_{i}$ が1を超えるもの はなかった。

尿中馬尿酸濃度を経時的に測定した結果，コントロー ル（7名）の濃度はすべて $1.0 \mathrm{mg} / \mathrm{ml}$ 以下であった. 塗装工 8 名のうち, 横引き型ブース内とブース外塗装に よって大量の暴露を受けた 3 名は, 湮装作業後, 1.0 $\mathrm{mg} / \mathrm{ml}$ を超える著名な馬尿酸濃度の上昇が認められた。 また，塗装工 8 名の尿中馬尿酸の平均濃度は $0.33 \mathrm{mg} /$ $\mathrm{ml}$, コントロール 7 名は $0.19 \mathrm{mg} / \mathrm{ml}$ であり, 塗装工 の尿中馬尿酸濃度はコントロールと比較して高い傾向が みられた。

\section{5. 個人サンプラーによる測定を中心とした家具塗装 工程の作業環境評価}

坪田信孝, 田村純子, 平岡幸夫
奥田久徳（広島大医衛生）

中川 茂（広島県医師会）

橋本説郎，緒方正名（岡山大医公衛）

有機溶剤中毒予防規則により；環境濃度測定が行われ ているが，とくに中小企業では同一作業者が複数の作業 を兼ねる場合が多く, 暴露量の判定が困難で市る。一 方，個人サンプラーは測定コストが高いなどの欠点があ る.

今回の調査では, 個人サンプラーによるトルェン濃度 測定のほかに, 最近の環境測定成績の収集, 当日の作業 条件に関する質問調查を行い，個人サンプラーと他の容 易に調查可能なデータを比較し，現状の作業状況の把握 を試みた。

解析に際し，対象者は複数の作業工程を兼视方場合が 多く単純には分類できなかったため, 各人の作業工程別 作業時間を变数として対象者をクラスター分析によって 分類した，その結果，主たる作業が荒叙，中塗，仕上 叙, 周辺作業である 4 群に分類でき，各群の他の工程と の兼業状況を把握できた。

その他の基本的データ处理と合斿せて以下の成績を得 た。

1）トルエン暴露量は，仕上>周辺>荒>中作慈群の 順であったが，環境測定成績のみでは周辺作業群が実際 の暴露量より低く判断される可能性が考兄られた。

2) 塗料使用量は溶剤含量と逆の関係をむち溶剤含量 より調査しやすく，溶凨使用量の目やすとしうる。

3）バッチによるトルエン測定は良好な測定が可能と 判断されたが，定常的調查は困難であるので，他の比較 的容易に得られる資料の評価方法を検討する上で有効と 考えられる.

4）その他，換気速度を下げる場合の対策，有機溶剤 暴露とは別に考学ても不快な温・湿度条件などにも注意 が必要と考光られた。

56. クリーニング作業従事者の死因調査（第 2 報） 中村 賢 (北里大医医療社会) 鈴木浩一，高橋英尚，門脇武博 相澤好治，一杉正治，高田 昆 佐々木洋実 (北里大医衛生公衛)

〔目的〕昨年本学会で，10年間のクリーニング作業従 事者の死因調查を行って発表した.

その後，生命共済制度加入者の年路別人口が調查でさ たので，標準化死亡比の算出を行った，一方，要因之の 関連をみるため, 最近 3 年間の履歷調查を実施したので, その結果について報告する.

[方法] 資料としては，昭和 46 年から昭和 55 年までの 
生命共済金請求資料を使用した，対象となった死亡者 は, 男 1,202 名, 女 507 名の 1,709 名で, 期待死亡数の 算出は，昭和50年の全国の 5 歳階級別死亡率を用いた。

また昭和54年から56年までの生命共済金請求資料で把 握された死亡者 517 名に対し, 死亡時の作業形態, 作業 歴，個人習慣に関する調查を笑施した。期待死亡数の算 ・出には，昭和50年の全国 5 歳階級別死亡割合を用いた。

【結果叔よび考察】(1) 全死亡でみると，全国とクリ 一ニング作業従事者の死亡率に，有意の差は認められな かった. (2)主要死因別にみると，男では「その他の心疾 患」，「精神病の記載のない老衰」で全国に比べ有意に高 いことが認めら机た，女では「その他の心疾患」，「精神 病の記載のない老衰」「肝臟の疾患」で全国に比べ有意 に高いことが認められた。 (3)部位別徳性新生物について は，女の「骨および関節軟骨」を除き，全国との間に有 意差は認められなかった。 (4)ドライ作業者の死亡時の平 均年龄は，非ドライ作業者に比べ男女とも若い傾向にあ ることが認められた. (5)ドライ作業者の「との他の心疾 患」，「肝臟の疾患」，「すべての肝疾患」等による死亡頻 度は，非ドライ作業者に比べ，高い傾向にあることが認 められた。今後さらに詳細な検討を行ら予定である。

座長のまとめ $(54 \sim 56)$

奥田久徳（広島大医衛生）

この 3 題はいずれも零細，小事業所に郝ける有機溶剤 業務にからさ報告であった。

54では，板金塗装を主体とする零細な自動車整備工場 に执いて，労働者の有機溶剂暴露状況を調査した成績が 報告された．暴露時間が短いことで救われているけれど も設備や作業方法には改善の余地があることが示され た。

55 では，家具製造工場の労働者について，活性炭バッ ジによる個人暴露量を中心に, 作業条件や環境測定成績 を検討した結果が報告され, 個人暴露量測定の有用性が 示された。

56では, クリーニング作業従事者の死因を調查し分析 した結果が報告された，若干の特定死因に有意の相違が 認められるとのことで興味深い報告であり，相違の原因 《ついて今後の研究の進展が期待される.なお, 新資料 が得られたとのことで, 講演集の表 $1 \sim 3$ は新しい数表 にさし替觉られた。

\section{7. 活性炭管による極性有機溶剤蒸気の捕集および 分析}

上野 浩, 内藤勝己, 藤木幸雄 （松下産業衛生科学セ）

低極性溶剤に対して，簡便に測定できる活性炭管を用
いた固体捕集法を使って，DMF，メタノール等の極性 溶剂に対して，一般には回収率が悪いとされていたが， $80 \%$ 以上の回收率が得られた。実際の作業環境中で, 極性，低極性の数種の混合溶剤であっても，1本の活性 孷管で同時に捕集でき，分析できることが示唆された。

すなわち，DMF の捕集実験では，試験濃度 400 $\mathrm{ppm}$ で採気量 $20 l$ まで $100 \mathrm{mg}$ の活性炭で捕集でき， このときの飽和吸着量は活性炭自重の $24 \%$ であり, ト ルエン等の低極性溶㓮の飽和吸着量と比べて差が見られ ず，他の捕集枋（シリカゲル，ポーラスポリマービー ズ）よりも優れていることがわかった.メタノールの捕 集実験では, 試験漂度や共存物質（高湿度, トルエン 等）にすかかわらず，100 mg の活性炭で 1 1.5lの破 過容量が存在することが示された.

これらの極性溶剤の脱着実験は, $\mathrm{CS}_{2}$ と精褩水の 2 相 の脱着液を用いて，水相の分配率（活性炭無“添加の場 合）が $95 \%$ 以上の極性溶剤に対して，水相の脱着率が $80 \%$ 以上であった。 また，この脱着液では，脱着率に 及ぼす負荷量（濃度）の影響が少なかった.

以上の結果から，極性溶剂でも，岕いは極性，低極 性の混合溶剤でも，採気量と脱着液を考慮すれば，活性 炭管を用いた固体捕集法で測定できることが示唆され た。

さらに，DMF の FID の検出限界は， $0.5 l$ の採気量 で 1 2 ppm と許容濃度に比べて感度が不十分なことが あるが，FTDを使用し，検出限界を 0.1 ppm まで下げ ることができた。しかし，FTD の分析精度の面で問題 点があり, 現在検討中である.

\section{8. 活性炭管に捕集した有機溶剤蒸気の脱着率} 小池慎也，芦田敏文 (神奈川県予防医学協会)

活性炭管は，有機溶剤蒸気の捕集に広く使用されてい るが，捕集した試料の脱着に関する検討報告は少ない。 そこで，活性炭管の脱着に影響を及ぼす諸要因について 検討を行い，あわせて試作した加熱脱着装置を用いて加 爇脱着について検討を行った。

活性炭量と脱着率の関係: 充媜量 $50,100,150,300$, $600 \mathrm{mg}$ の活性炭管を用い，4試料溶剂について TLV （TLV の濃度の蒸気を $5 l$ 捕集した絶対量）を添加して 吸着させたのち, $1 \mathrm{ml} の \mathrm{CS}_{2}$ で脱着を行って脱着率を 求めた。 その結果，脱着率は活性炭量の少ない場合には 比較的良好であったが，活性炭量が多くなるにしたがい 低下することを認めた。

試料添加量（捕集量）之脱着率の関係：8試料溶剂に いつて, TLV の $1 / 2 ， 1 ， 2$ 倍相当量を充填量 $100 \mathrm{mg}$ 